\title{
First record of Trachycaris restricta (A. Milne-Edwards, 1878) (Crustacea, Hippolytidae) from the State of Sergipe, northeast Brazil: Filling distribution gaps
}

\author{
Glauber Santana de Sousa*, Mariana Andrade Oliveira de Carvalho, Carmen Regina Parisotto \\ Guimarães \\ Universidade Federal de Sergipe, Departamento de Biologia, Núcleo de Ecossistemas Costeiros. Av. Marechal Rondon, s/no., CEP: 49000-000. \\ São Cristóvão, Sergipe, Brazil. \\ * Corresponding author. E-mail: glauberufs@gmail.com
}

\begin{abstract}
This paper presents the first record of Trachycaris restricta (A. Milne-Edwards, 1878) from the State of Sergipe, filling a gap of occurrence of this species in the Brazilian northeast coast and compiles previous reports of this species from Brazil. The analyzed specimens were associated with algae and captured through daytime fishery hauls in two sampling stations at 30 m depth in March 2000.
\end{abstract}

DOI: $10.15560 / 10.5 .1204$

The family Hippolytidae Dana, 1852 is composed of 22 genera, in which the genus Trachycaris Calman, 1906 comprises only two species, Trachycaris rugosa (Bate, 1888) and T. restricta (A. Milne-Edwards, 1878). The first species occurs in the Western Atlantic and the second species in the Eastern Atlantic. Several studies have indicated the occurrence of T. restricta in the Brazilian coast (Ortmann 1893; Coelho and Araújo Ramos 1972; Coelho et al. 1978, 1980; Christoffersen 1979; Fausto Filho 1980; Ramos-Porto 1980; Ramos-Porto and Coelho 1991/93; Cardoso 2006) from the states of Amapá to Espírito Santo and apparently along the whole? northeast coast of Brazil. However, although Coelho et al. (1978) stated that T. restricta is a "continuous tropical" species presenting a continuous distribution from the Antilles to the northeast of Brazil (including Espírito Santo State), no publication mentions the capture of this species in the state of Sergipe. The specimens analyzed herein were collected in a coastal oceanographic campaign that monitored the impact of oil platforms off the coast of Sergipe and are deposited in the Zoological Collection, Benthos Coastal Laboratory, Sergipe Federal University (voucher numbers UFS-CRU 0012 and UFS-CRU 0013). The specimens were captured during daytime in March 2000 (dry season), in bottom trawls of 15 minutes at two sampling stations on the continental shelf at 30 $\mathrm{m}$ depth (Figure 1). In Sergipe, the continental shelf's bottom sediments are influenced by the presence of the São Francisco River to the north and also by four other estuarine complexes, besides two submarine canyons (São Francisco and Japaratuba) that are situated less than $12 \mathrm{~km}$ away from the coastline. Although the coast of Sergipe presents characteristics that suggest a muddy platform, it possesses a sedimentary mosaic with predominance of terrigenous muds at the coastal region and sands, gravels and carbonate muds toward offshore. The presence of macroalgae and carbonate bottoms in two small regions allowed the formation of a favorable habitat to $T$. restricta.

Seven specimens of $T$. restricta were found associated with macroalgae in an environment with gravelly sedimentary facies and large biomass of algae, corroborating the general information in the literature regarding its habitat. The specimens were identified according to Houthuis (1949) and Cardoso (2006). Trachycaris restricta occurs at depths ranging from 18 to $100 \mathrm{~m}$ in sandy, muddy, rocky, coral and coralline algae bottoms (Ortmann 1893; Coelho and Araújo Ramos 1972; Coelho et al. 1978; Christoffersen 1979; Fausto Filho 1980; Ramos-Porto 1980; Cardoso 2006). Table 1 presents works mentioning the occurrence of T. restricta in the Brazilian coast with records based on samplings.

According to Cardoso (2006), in 1949 Holthuis compared specimens of T. rugosa from the Canary Islands with specimens of Hyppolyte restrictus from Curacao (Antilles) and concluded that both species were actually only one, naming it Trachycaris restricta. However, Criales (1992) analyzed 19 mature females from the Western Atlantic and concluded that all of them, except for one specimen, possessed similar features to the description for T. rugosa. Thus, Criales (1992) concluded that the two species are valid, with $T$. restricta (Figure 2A) having as its main distinguishing features: presence of mandibular palp (Figure 2B); 3 spines on basal antennal peduncle (Figure 2C) and first maxilliped with unsegmented palp (Figure 2D), corroborating with the species in this paper. Trachycaris rugosa has no record for the Brazilian coast.

Order Decapoda Latreille, 1802

Infraorder Caridea Dana, 1852

Superfamily Alpheoidea Rafinesque, 1815 

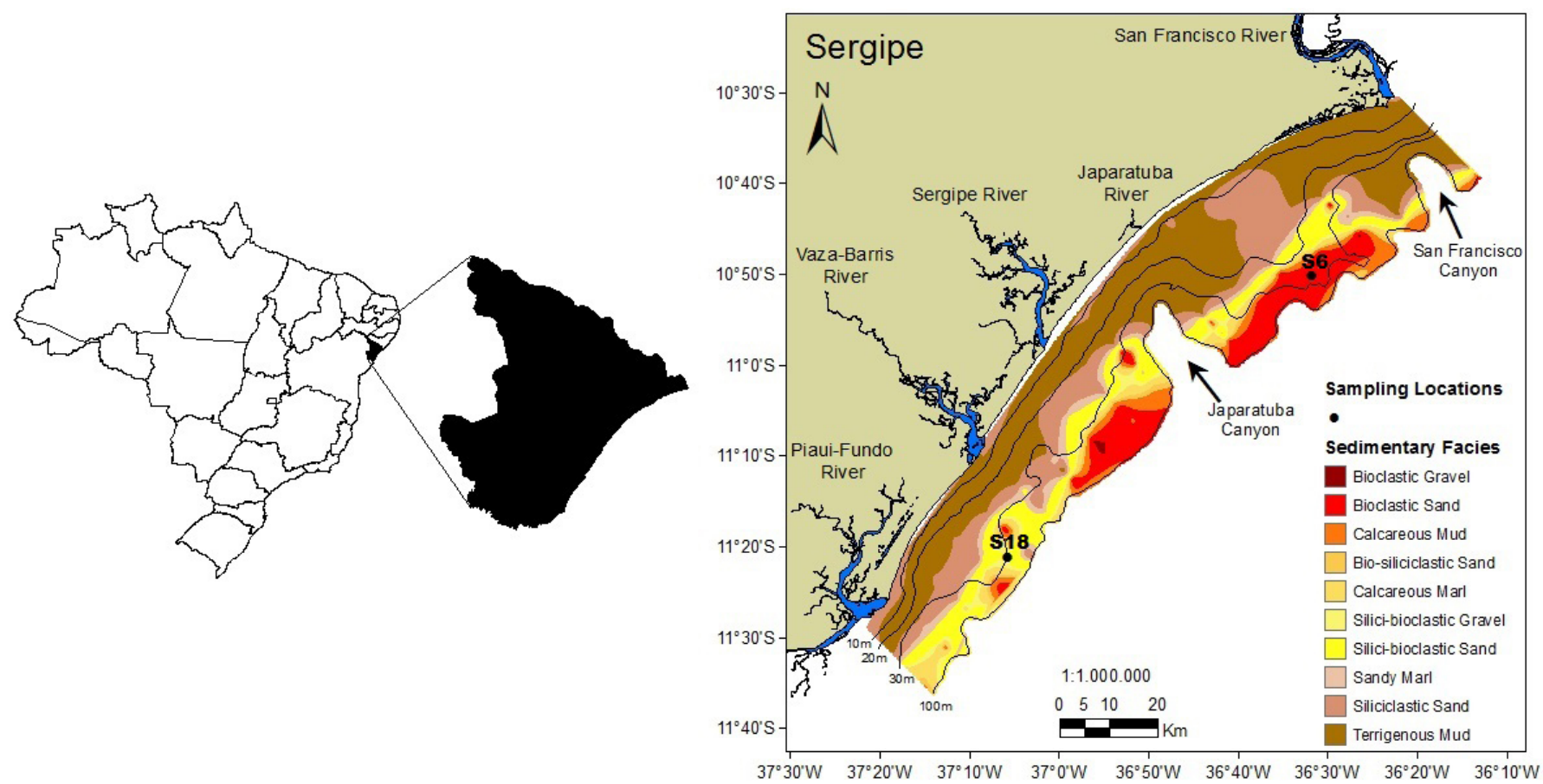

FIGURE 1. Map of the state of Sergipe, indicating the samplings locations (S6 and S18).

Family Hippolytidae Spence Bate, 1888

Genus Trachycaris Calman, 1906

Trachycaris restricta A. Milne-Edwards, 1878

Diagnosis: Carapace tuberculate, with teeth and tuffs of setae; rostrum laterally flattened, as long as high, dorsal margin with 8-13 teeth, distal margin with 3-6 small teeth, lower margin with 3 broad teeth, dorsal carina with 5-7 teeth; antennal spine strong and acute, 2-3 small teeth on anterolateral angle. Stylocerite broad ending in 2 processes, proximal one acute and distal rounded, with strong teeth. Scaphocerite with small distal tooth, not overreaching blade.

Material examined: 3 males (carapace length 1.80$2.50 \mathrm{~mm}$ ) and 1 ovigerous female (carapace length 4.07 $\mathrm{mm}$ ), $11^{\circ} 21^{\prime} 07^{\prime \prime} \mathrm{S}, 37^{\circ} 05^{\prime} 50^{\prime \prime} \mathrm{W}$, station $18,30 \mathrm{~m}$ (UFS CRU_0012). Water temperature: $26^{\circ} \mathrm{C}$; salinity: $34.1 \%$; bottom sediment: coarse sand and gravel; organic matter content: $9.0 \%$; calcium carbonate content: $35.8 \%$.

3 ovigerous females (carapace length $4.07-4.13 \mathrm{~mm}$ ), $10^{\circ} 49^{\prime} 47^{\prime \prime} \mathrm{S}, 36^{\circ} 32^{\prime} 10^{\prime \prime} \mathrm{W}$, station 6, 30 m (UFS_CRU_0013).
Water temperature: $26^{\circ} \mathrm{C}$; salinity: $34.7 \%$; bottom sediment: coarse sand and gravel; organic matter content: $5.2 \%$; calcium carbonate content: $38.9 \%$.

This is the first record of T. restricta for the state of Sergipe, confirming the northeast coastal distribution of $T$. restricta, as well as its association with carbonate environments and macroalgae.

ACKNOWLEDGMENTS: This work was conducted with Petrobras support through the agreement FAPESE/UFS 25/99 and the contract PETROBRAS/FAPESE 120.2.010.99-1. We would like to thank the biologist Luana Mendonça for taking and processing the photographs.

\section{LITERATURE CITED}

Cardoso, I. 2006. Caridea (Crustacea, Decapoda) collected on the Brazilian $\left(13^{\circ} / 22^{\circ} \mathrm{S}\right)$ continental shelf and slope. Zootaxa 1364: 1-44.

Christoffersen, M.L. 1979. Decapod Crustacea: Alpheoida. Campagne de la Calypso au large des côtes atlantiques de l'Amérique du Sud (1961-1962). I. Resultats scientifiques des Campagnes de la Calypso. Annales de l'Institut Océanographique Monaco, Supplement 55: 297377.

Coelho, P.A., M. Araújo Ramos. 1972. A constituição e a distribuição da fauna de decápodas do litoral leste da América do Sul entre as latitudes $5^{\circ} \mathrm{N}$ e $39^{\circ} \mathrm{S}$. Trabalhos Oceanográficos da Universidade

TABLE 1. Occurrences of Trachycaris restricta (A. Milne-Edwards, 1878) at the Brazilian coast. (AP) - Amapá. (PA) - Pará. (CE) - Ceará. (PB) - Paraíba. (PE) - Pernambuco. (BA) - Bahia. (SE) - Sergipe. (ES) - Espírito Santo.

\begin{tabular}{|c|c|c|c|c|}
\hline CITATIONS FROM BRAZIL & STATES & GEOGRAFIC COORDINATES & DEPTH (m) & воттом \\
\hline Ortmann 1893 & PA & - & $50-100$ & - \\
\hline Coelho and Araújo Ramos 1972 & Ocean bank (CE), CE, PB, PE, BA, ES & - & $47-68$ & calcareous algae \\
\hline Christoffersen 1979 & $\mathrm{BA}$ & $\begin{array}{l}12^{\circ} 56.4^{\prime} \mathrm{S}, 38^{\circ} 33.5^{\prime} \mathrm{W} \\
16^{\circ} 46^{\prime} \mathrm{S}, 38^{\circ} 53^{\prime} \mathrm{W} \\
18^{\circ} 09^{\prime} \mathrm{S}, 38^{\circ} 20^{\prime} \mathrm{W} \\
18^{\circ} 09^{\prime} \mathrm{S}, 38^{\circ} 30^{\prime} \mathrm{W}\end{array}$ & $\begin{array}{l}18 \\
27 \\
33 \\
50\end{array}$ & $\begin{array}{l}\text { sand, calcareous algae, } \\
\text { mud, rock, coral }\end{array}$ \\
\hline Fausto Filho 1980 & CE, PB, PE & - & $47-68$ & gravelly \\
\hline Ramos-Porto 1980 & $\mathrm{PE}$ & $7^{\circ} 40^{\prime} \mathrm{S}, 34^{\circ} 28^{\prime} 7^{\prime \prime} \mathrm{W}$ & $60-68$ & calcareous algae \\
\hline Ramos-Porto and Coelho 1991/93 & AP, CE, PB, PE, BA, ES & - & $47-99$ & calcareous algae \\
\hline Cardoso 2006 & $\mathrm{BA}$ & $16^{\circ} 47^{\prime} 13^{\prime \prime} \mathrm{S}, 38^{\circ} 41^{\prime} 48^{\prime \prime} \mathrm{W}$ & 50 & - \\
\hline Present study & SE & $\begin{array}{l}11^{\circ} 21^{\prime} 07^{\prime \prime} \mathrm{S}, 37^{\circ} 05^{\prime} 50^{\prime \prime} \mathrm{W} \\
10^{\circ} 49^{\prime} 47^{\prime \prime} \mathrm{S}, 36^{\circ} 32^{\prime} 10^{\prime \prime} \mathrm{W}\end{array}$ & 30 & gravelly \\
\hline
\end{tabular}




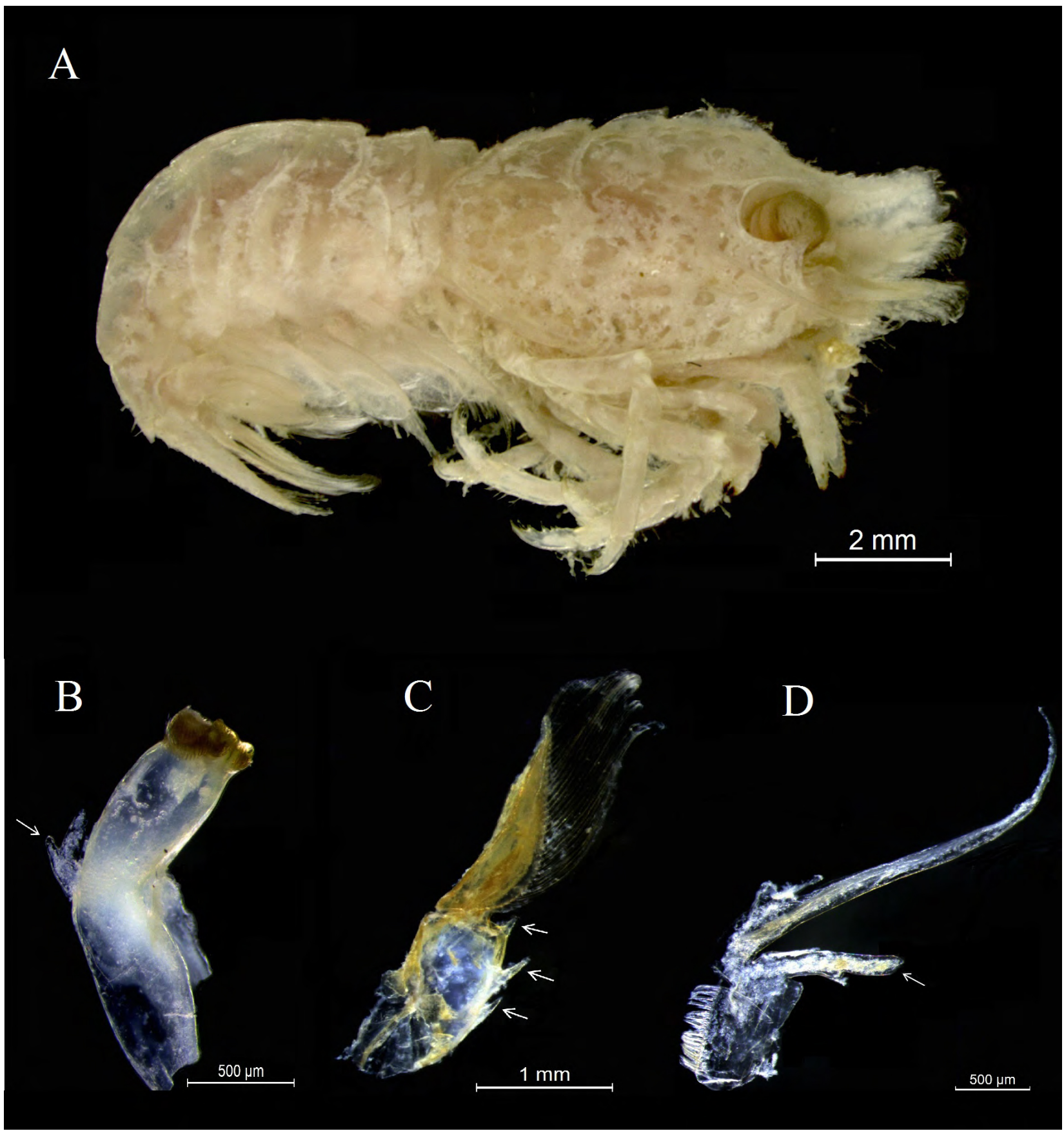

FiguRE 2. Trachycaris restricta (A. Milne-Edwards, 1878); CRU_0013, female, carapace length 4,09 mm. (A) lateral view; (B) mandible, arrowmandibular palp; (C) antenna, arrows—spines on basal antennal peduncle; (D) first maxilliped, arrow—unsegmented palp.

Federal de Pernambuco 13: 133-236 (http://www.revista.ufpe.br/ tropicaloceanography/volumes/volume_13_1972.html).

Coelho, P.A., M. Ramos-Porto, M.L. Koening. 1978. Crustáceos marinhos do Brasil, do Uruguai e da Argentina (ao norte de Mar del Plata): considerações biogeográficas. Anais da Universidade Federal Rural de Pernambuco 2/3: 227-256.

Coelho, P.A., M. Ramos-Porto, M.L. Koening. 1980. Biogeografia e bionomia dos crustáceos do litoral equatorial brasileiro. Trabalhos Oceanográficos da Universidade Federal de Pernambuco 15: 7-138 (http://www.revista.ufpe.br/tropicaloceanography/volumes/ volume 15 1980.html).

Criales, M.M. 1992. Redescription of the hippolytid shrimp Trachycaris rugosa (Bate) (Crustacea: Decapoda: Caridea) from the Western Atlantic, with notes on sexual dimorphism. Proceedings of the Biological Society of Washington 105: 562-570 (http:// biodiversitylibrary.org/page/35607741).

Fausto Filho, J. 1980.Crustáceos estomatopodos e decápodos dos substratos de cascalho do nordeste brasileiro. Arquivos de Ciências do Mar 20(1): 101-124.
Holthuis, L.B. 1949. The caridean Crustacea of the Canary Islands. Zoologische Mededelingen 30(15): 227-255.

Ortmann, A. 1893. Decapoden und Schizopoden der Plankton Expedition Ergebnisse der Plankton-Expedition 2 (Gb): 1-120, pls. 1-10.

Ramos-Porto, M. 1980. Estudo ecológico da região de Itamaracá, Pernambuco, Brasil. VII Crustaceos Decapodos Natantes. Trabalhos Oceanográficos da Universidade Federal de Pernambuco 15: 277-310 (http://www.revista.ufpe.br/tropicaloceanography/volumes/volume 15_1980.html).

Ramos-Porto, M., P.A. Coelho. 1991/93. Sinopse dos crustáceos decápodos brasileiros (Família Hippolytidae). Trabalhos Oceanográficos da Universidade Federal de Pernambuco 22: 181-189 (http:// www.revista.ufpe.br/tropicaloceanography/volumes/volume _22_1991_1993.html).

Received: April 2014

Accepted: September 2014

PUBLISHED ONLINE: October 2014

EDITORIAL RESPONSIBILITY: Luis Ernesto Arruda Bezerra 